\title{
Fleshing out the Landscape: Two centuries of Australia's geological heroes
}

\author{
School of Geosciences, University of Sydney, NSW 2006, Australia. E-mail: dbranaga@mail.usyd.edu.au
}

Australian Geology, from its beginning, was linked to the development of resources, in a number of distinct colonies, often with little co-operation between them. While the formation of the Commonwealth in 1901 saw the beginning of an Australia-wide approach to geological studies, the former colonies, now states, still guarded certain rights, acting independently, in as far as possible. Separate colonial geological surveys continued as State bodies, focussed largely on resource (including water) studies. Geological education was mainly through a few universities, where research on broader issues was undertaken, with results published in separate, largely colony/state oriented, society journals. The Australasian Association for the Advancement of Science, formed in 1888, was a major influence in bringing geologists into direct contact, and marked the beginning of attempts to rationalise results and focus on Australia-wide aspects. Post World War 11 saw the expansion of geological research, formation of a Commonwealth Survey and the Geological Society of Australia, with the latter providing a medium for promulgation and discussion of ideas. The paper discusses the role of some 180 geologists through two centuries.

\section{Introduction}

Australia, the island continent, is very large (Figure 1). Its size and physical characteristics offered considerable challenges to the original Aboriginal inhabitants, and the Europeans and Asians who first visited, and then settled, in the country. The Aboriginal peoples had a considerable feeling for landscape, particularly aspects relating to ease of travel, but which also embraced spiritual concepts of the close relation of land to humanity, shown in the 'song lines' linking many parts of 'country'. Knowledge of the location, use and trade of natural materials was both extensive and detailed, numerous 'mining sites' supplying materials for axes, spear-heads, grinding stones, ornamental items and ochre. There was also teaching and identification of 'sacred sites' for initiation and other ceremonies, such sites often inscribed by 'real pictures', time markers or symbolic spiritual images. Although there is little documentation of specific individuals who preserved and passed these matters on to later generations, it is known that Aboriginal people guided European prospectors to outcropping mineralisation during the $19^{\text {th }}$ century. One such European was Ernest Henry, led by Kalkadoon people to the Argylla and Mt. Oxide sites in the Cloncurry region, NW Queensland, 1880-82 (Blainey, 1960).

From European settlement (1788) until 1940, fewer than 1,000 geologists had worked in Australia. About 300 had been members of the Geological Society of London (F.G.S.) formed in 1807. Others belonged to local scientific societies, and, from the 1890s, the Australasian Institute of Mining Engineers (later The Australasian Institute of Mining and Metallurgy). An exponential increase in the number of geologists occurred about 1950, when many graduated and were employed by Commonwealth and State government surveys and research bodies. Projects such as the Snowy Mountains Hydro-Electric Scheme recruited geologists, as did mining and exploration companies. There was also demand for teachers in tertiary institutions. Geologists migrating from Europe and North America added a new mix to an environment which had traditionally been wedded to British practices. Today, approximately 4,000 geologists work in Australia.

Since the last International Geological Congress held in Australia (the $25^{\text {th }}, 1976$ ), there has been growing interest in the origins and progress of Australian geology, as summarised in this paper. With several exceptions, only non-living geologists are included in the account, and the story is taken only to the mid 1960s. The paper does not discuss the major theoretical problems of Australian geology, such as the Gondwana concept, ancient glaciations, desert landforms, geomorphology in general or geophysics (for which see Vallance, 1975; Branagan and Townley, 1976; Day, 1966).

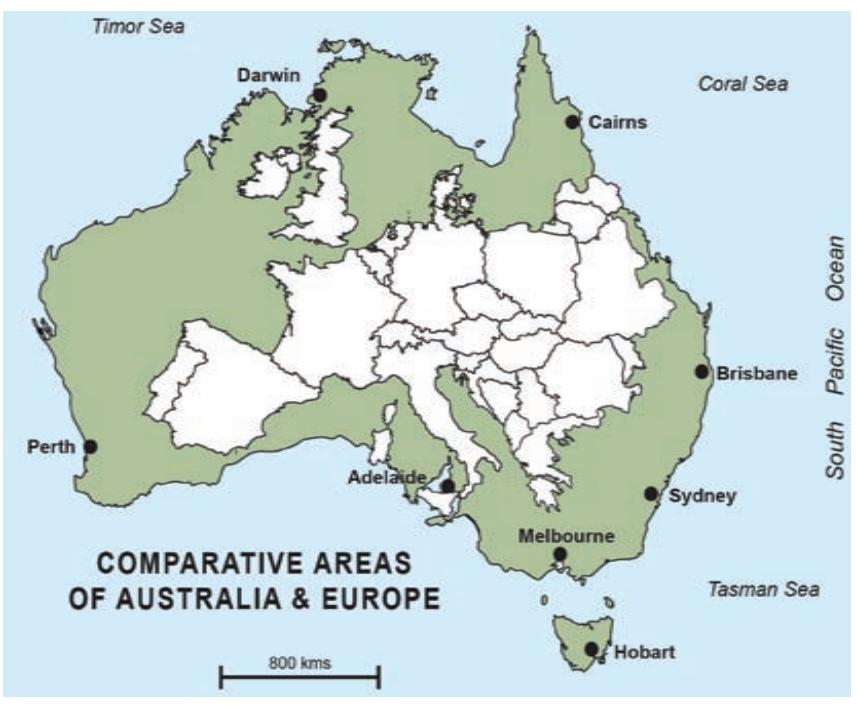

Figure 1 Comparison of Australia and Western Europe. 


\section{Early European Settlement and Exploration (1788-1850)}

\section{European Geologists, Sydney 1788-1812}

The first European settlement in 1788 (the Colony of New South Wales) owed its position to the splendid Sydney Harbour, just $\mathrm{N}$ of Cook's Botany Bay. While 'the finest harbour in the world' was a distinct advantage, the rugged basin-like geological structure surrounding Sydney restricted expansion, confining development for almost twenty years. Settlers had to fend for themselves, and while excellent sandstone, and clay (weathered shale) for bricks were readily available, lime was scarce, only sea shells - in accumulations from Aboriginal feasts - offering limited sources of this essential building material. Availability and storage of water was a continuing problem.

The British authorities, perhaps hoping the colony would quickly become self-sufficient, appointed a mineralogist, Adolarious W.H. Humphrey (1782-1829), in 1803. He worked first in Tasmania and moved to Sydney in 1805, but resigned in 1812 to become a magistrate. His contribution to geological knowledge was slight (Vallance, 1981a). In the meantime, coal, discovered in 1791 at Newcastle, $120 \mathrm{~km} \mathrm{~N}$ of Sydney, was already being mined by the Australian Agricultural Company.

\section{The French}

In the early years of British settlement, the French also explored the Pacific region. Their expeditions carried savants, who collected minerals, rocks and fossils. The d'Entrecasteaux expedition (17921793) made geological observations around Tasmania, mainly though the scientist J. La Billardière (1755-1834), noting spectacular columnar dolerite coastal outcrops, limestone on Bruny Island, and describing coal seams and associated rocks at South Cape Bay, southern Tasmania. That coal (now known to be Triassic) was assumed to be the same age as European coal, later called 'Carboniferous', an assumption marking the beginning of a seventy-year long controversy about coal ages in Australia (Vallance, 1981b).

The Baudin (1754-1803) expedition (1800-1804) included geologically-trained Louis Depuch (1774-1803) and Joseph Charles Bailly (1777-1844) and the zoologist, François Péron (1775-1810). They observed aeolian calcareous coastal sandstones on the Western Australian and South Australian coasts, while Peron's geological observations on Maria Island off Tasmania were perceptive (Banks, 1990). Depuch and Bailly, the first geological visitors to Sydney, recognised the stratigraphic relations between the boldly-outcropping (Hawkesbury) sandstone and the overlying shale, and collected pebbles of granites and metamorphics (as we know them) in the Nepean River, $60 \mathrm{~km} \mathrm{~W}$ of Sydney, carried from the as-then uncrossed (by Europeans) Blue Mountains, suggesting that 'the mountains whence it [the river] takes its rise are themselves of a Primitive nature' (Mayer, 2005). The expedition's collection (796 specimens) was described by the German Leopold von Buch who suggested that rocks lithologically similar to those found in Europe might not necessarily be of the same geological age (Von Buch, 1814). The French-born Francis Barrallier (1773-1853), a British army officer, is now thought to have been the first European to traverse the sandstone barrier SW of Sydney, and he made important discoveries, including fossils (Mayer, 2007).

Louis de Freycinet's expedition (1817-1820) included J.R.C.
Quoy (b. 1790), who described the Shark Bay (WA) reefs, and added to the understanding of Sydney region geology. The Duperrey expedition (1822-1825) included R. P. Lesson, whose observations of the igneous rocks (Prospect doleritic intrusion, $45 \mathrm{~km} \mathrm{~W}$ of Sydney, and the Bathurst granite, beyond the Blue Mountains), and his attempt to establish a stratigraphic succession for the region, were noteworthy.

\section{John Busby, the Second Colonial appointment}

Despite Humphrey's relatively unsuccessful tenure, in 1823 the British Government appointed the experienced 'mineral surveyor', John Busby (1765-1857). He reported on the Newcastle coal mines, being worked by the Australian Agricultural Company (Pemberton, 1986). Busby examined iron ore sites, but they were not economic, even in a colony desperate for such material. However, he soon became involved in improving Sydney's water supply, identifying a suitable source $4 \mathrm{~km} \mathrm{~S}$ of Sydney, cutting an inclined tunnel through the intervening sandstone ridge, pumping the water to the southern portal and gravitating the water to the town centre. It took twelve years to complete (Thorpe, 1953).

\section{Observant Settlers and Visitors}

Geological observations by long-term residents began in the 1820s. They included: Phillip Parker King (1791-1856), who, while circumnavigating Australia, made rock collections from many sites that were later described in London by William H. Fitton (1780 1861) (Branagan and Moore, 2008); the Reverend C.P.N Wilton (1795-1859); and the explorer-surveyor (Sir) Thomas Mitchell (17921855). The Reverend T.H. Scott (1783-1860) published a widely circulated paper on the geology of New South Wales and Tasmania (Scott, 1824). Another paper by Scott (1831), based on an enforced stay in Western Australia, was one of the earliest about the Swan River settlement.

Wilton, based for years at Newcastle, studied the stratigraphy, and published the first details of the 'Burning Mountain' at Wingen, initially thought to be an active volcano, but soon identified as a burning coal seam (Wilton, 1829; Mayer, 2009). In 1829, the 'Mountain' was also visited by Mitchell who had learnt the skills of military draftsmanship and landscape sketching during the Peninsular Wars. He joined the Geological Society of London and received geology tuition from Fitton. Mitchell made major contributions to Australian geology, mapping in the Sydney region (Figure 2), later in the central-west of New South Wales, and collected important vertebrate fossils from caves, described by European experts (Oldroyd, 2007). His 'eye for country' helped him build roads for the difficult terrain surrounding Sydney, establishing transport corridors that, for the most part, remain essentially unchanged.

In the 1830s the enigmatic Pole, John Lhotsky (1832), the later famous Charles Darwin (1836), Paul Strzelecki (1839) and the Reverend W.B. Clarke (1839) arrived in Australia. Lhotsky (18001866) was not popular, so his work, during his six-year stay was (and has been since) undervalued. Lhotsky is remembered for his journey from Sydney to the Australian Alps, early in 1834, which included important mineralogical, geological and geographical observations (Vallance, 1977). In Tasmania (1836-1838), he recorded seven lithostratigraphic units on an unpublished map of the Port Arthur region.

Darwin's visit, to Tasmania, New South Wales and Western 


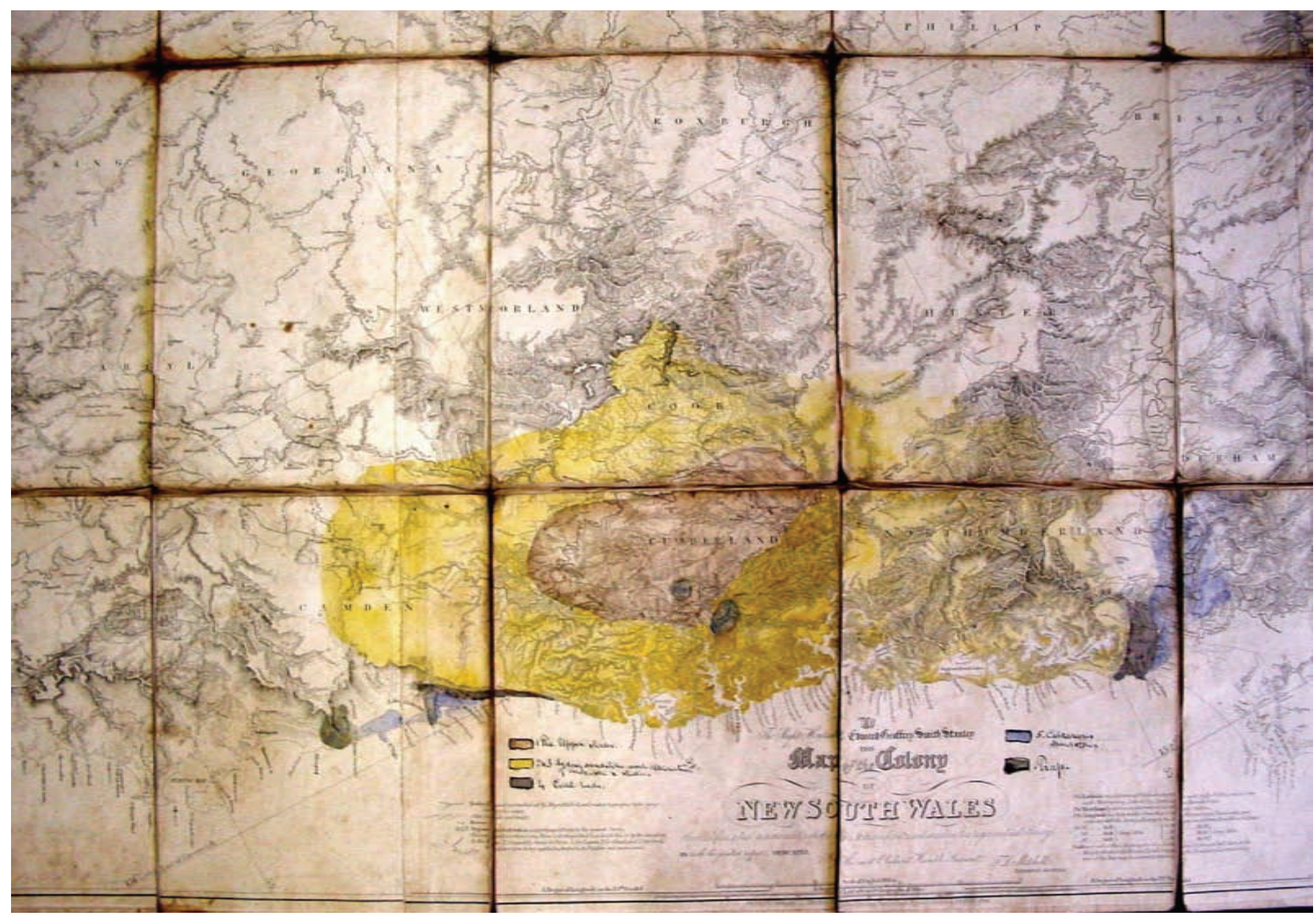

Figure 2 T.L. Mitchell's Manuscript Geology of the Sydney Region Map, c. 1830.

Australia (Nicholas and Nicholas, 1989), is well known. While his observations were generally good, his interpretation of the scenery was sometimes wrong. Influenced by Charles Lyell's ideas, he thought the Blue Mountains valleys were formed by marine erosion.

In contrast with Lhotsky, Strzelecki (1797-1873), another Pole, charmed everyone. He had studied geology in France; gained geological and mining experience in the Americas, saw active volcanism in Hawaii, visited Tahiti and New Zealand, arriving in Sydney in April 1839. While controversy continues about his ascent of Australia's highest peak, Mount Kosciuzsko, his geological observations in Tasmania and eastern Australia, entered on a huge map, with numerous crosssections, were important (Branagan, 1986). His book (Strzelecki, 1845; Paszkovski, 1997), with fossil identifications by British experts, gained considerable acclaim.

Cambridge graduate William Branwhite Clarke (1798-1878), often called the 'Father of Australian Geology', is the best known of early Australian geologists (Figure 3). Arriving in poor health he found the climate suited him. During thirty-five years

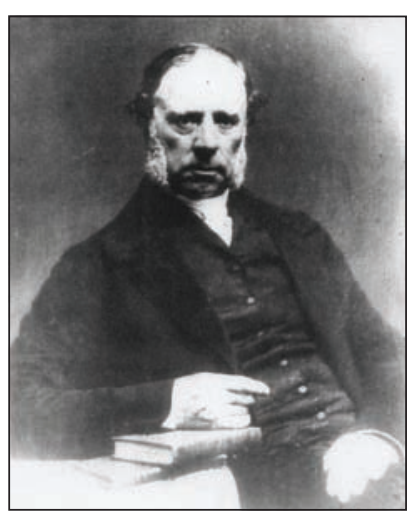

Figure 3 The mature Reverend W.B. Clarke (c. 1860). in the colonies he combined his clerical duties with geology. Although most of his geological work was done in New South Wales (including now southern Queensland), he paid a short visit to Tasmania in 1855. Clarke maintained correspondence with British and continental European geologists and with other colonial workers (Moyal, 2002). He was a major influence on the early development of Australian geology, with his writings and mapping, but was perhaps too wedded to European stratigraphic concepts, tending to 'push' his observations to fit them. His Researches in the Southern Goldfields (1860), The Sedimentary Formations of New South Wales (1867), and his map of New South Wales (Figure 4) exemplify his work.

Ludwig Leichhardt (1813-1848?) came to Australia in 1842 with a fine geological background, from two years of studying with the best French geologists. He thought geological events in Australia might not have the same time frame as in Europe. His reputation as an explorer and scientist suffered for years from biased, inaccurate studies, and his important geological papers (Leichhardt, 1855, 186768) were largely ignored. Aurousseau (1968) and Roderick (1988) provide a more accurate and balanced picture. His diaries (translated by T.A. Darragh), with their revealing notes and geological sketches, await publication.

Joseph B. Jukes (1811-1869), naturalist on HMS Fly, spent three years in the Australian region, meeting Strzelecki and Clarke. He published an important report on the geology of the Great Barrier Reef and summarised the known geology of the continent (Jukes, 1850). 


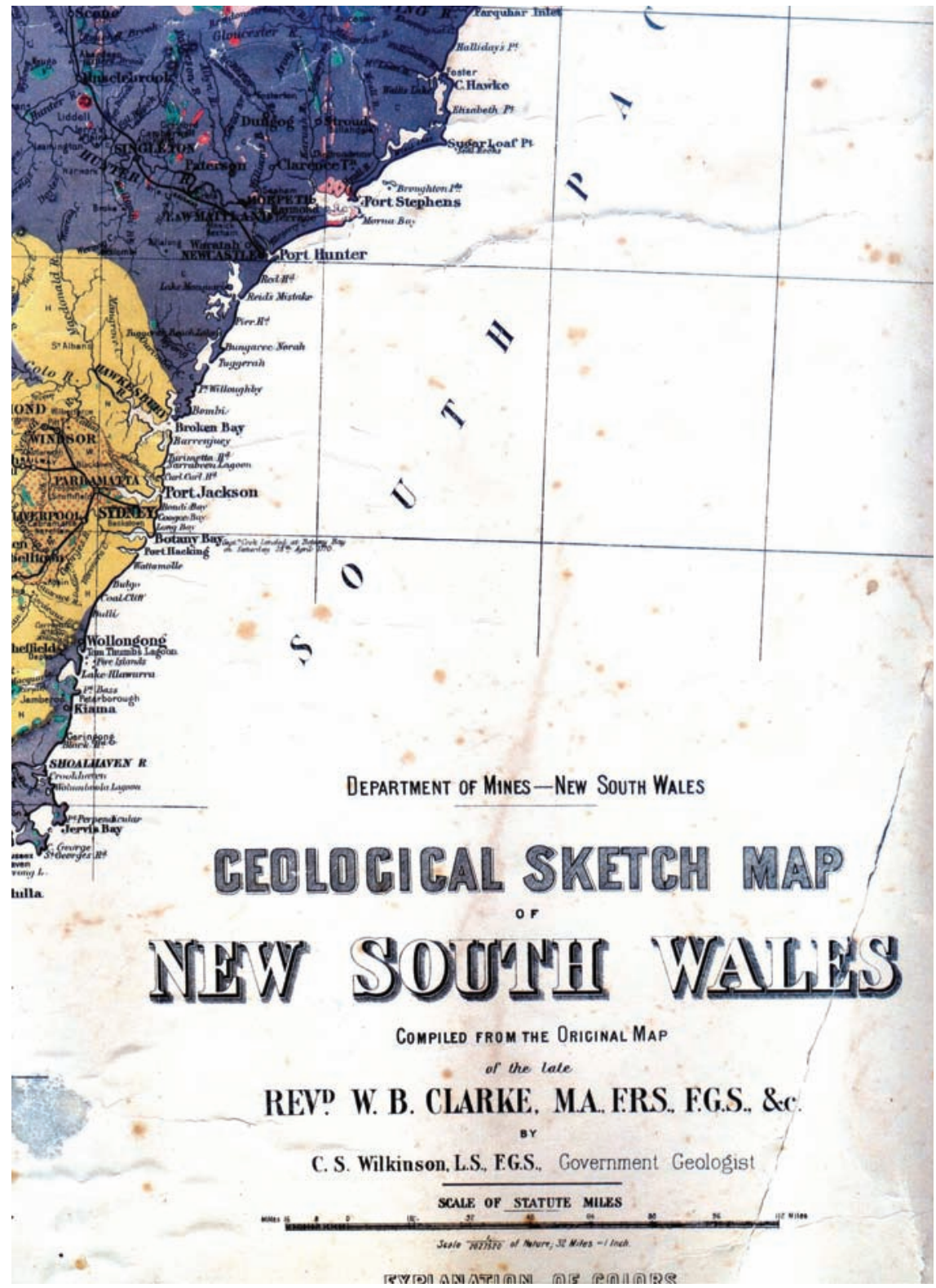

Figure 4 Portion of W.B. Clarke's Geological Map of New South Wales, edited and published by C.S. Wilkinson, 1880.

\section{Colonial Geological Surveys}

European settlement began at different times in separate and independent colonies, which maintained competitive independence until the country was united in the Commonwealth of Australia in 1901. Official colonial interest in geology varied considerably over the years. It diminished when Busby retired, but mineral discoveries in several colonies, in the 1840 s and early 1850 s, revived Government involvement. All the Colonial (later State and Commonwealth) geological surveys established were initially linked to mining and other practical matters, including water supplies.

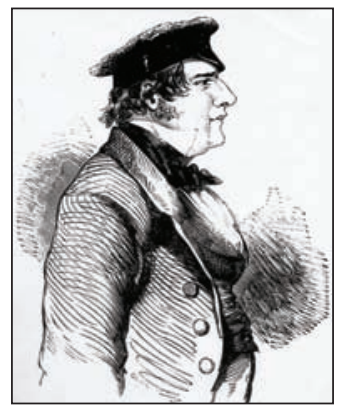

Figure 5 Samuel Stutchbury, Mineral Surveyor, NSW, 1850-1855.
In 1850, New South Wales appointed Samuel Stutchbury (1797-1856) Mineral Surveyor. Stutchbury (Figure 5) had spent three months in New South Wales in 1825-1826, and had extensive mining geology experience in Wales and Cornwall. However, the Government showed little interest in his geological observations, expecting him to be a trained prospector. Stutchbury spent four lonely years working $\mathrm{W}$ of Sydney and then $\mathrm{N}$ as far as Gladstone (in present Queensland), mapping some $80,000 \mathrm{~km}^{2}$, producing informative quarterly reports, with maps and sections. $\mathrm{He}$ suffered from the antagonism of Clarke, who also worked for a time for the Colonial Government on the search for gold. After Stutchbury returned to England in 1855 the Government relied on coal examiners William Keene (1798-1872) and John Mackenzie for geological advice, until 1875, when a Department of Mines and a Geological Survey were established (see below).

\section{Alfred Selwyn and his Victorian Geological Survey}

The most successful of the Colonial Surveys commenced in 1852 , following the discovery and rapid exploitation of gold in Victoria, when Alfred R.C. Selwyn (1824-1902) (Figure 6), left the Geological Survey of Great Britain to take up this better paid appointment. Selwyn had gained valuable experience in Britain, mapping Lower Paleozoic rocks in Wales under Andrew Ramsay (1814-1891). He had also mapped coalfields and had an interest in glaciation. An enthusiast for mapping he began fieldwork immediately he arrived in Australia in December 1852, preparing a fine map of the Castlemaine goldfield, NW of Melbourne.

In 1854, Richard Daintree (1832-1878) and Norman Taylor (1834-1894) were appointed to assist Selwyn. Christopher D'Oyly Aplin (c. 18191901) joined them in 1856, when an official Geological Survey, with Selwyn as Director, was established. He adopted the British Quarter Sheet system, producing rectangular base maps, six miles by nine miles (scale 1: 31,680). Unlike Britain, there were few surveyed regions, so the geologists had to spend considerable time on topographic mapping as well as recording geological data, so progress was often slow. Nevertheless up to its closure in 1868 Selwyn's Geological Survey prepared and published 65 such maps, covering much of Victoria's mineralised region, and gaining a high reputation internationally (Darragh, 1987). In 1863, Figure 6 Alfred Selwyn, the first Geological Map of Victoria was first Director of the published - the first for any Australian Geological Survey of Colony. 
From 1858 Selwyn added George Ulrich (1830-1900), Charles S. Wilkinson (1843-1891), Reginald A.F. Murray (1846-1925), E.J. Dunn (1844-1937), H.Y.L. Brown (1844-1928), the paleontologist Robert Etheridge Jr. (1846-1920), and a chemical laboratory to the Survey. Important petrological work, especially on metamorphic rocks, was accomplished by A.W. Howitt (1830-1908). The Survey was closed in 1868, partly through the machinations of Robert Brough Smyth (1830-1889), Secretary of Mines from 1861 (Darragh, 2000). In consequence, Selwyn moved to Canada to direct the Geological Survey when William Logan (1798-1875) retired the following year. Of Selwyn's staff, Ulrich prospered in New Zealand, whereas the others subsequently had fine careers elsewhere in Australia (see below).

\section{The New South Wales Survey begins}

After closure of the Victorian Survey, Wilkinson was a land surveyor in NSW, but re-established his geological career there, when a Geological Survey, under his charge, was established in 1875. It has continued to the present, and like all the Colonial (later State) Surveys, has had 'ups and downs'. Initially Wilkinson had only Charles Cullen, 'fossil collector', as assistant. They made a large collection for a Geological and Mining Museum, opened in 1876. In 1878, E.F. Pittman (1849-1932) and H.G. Lamont Young (1851$1880)$, and in 1879 J.E. Carne (1855-1922) joined. Young and his assistant M.K. Schneider disappeared mysteriously in 1880, on a survey of the newly discovered south coast Bermagui Goldfield, and were never found. Young's replacement was H.Y.L Brown, another from Selwyn's Survey. In 1882 Brown moved to South Australia. The same year, T.W. Edgeworth David (1858-1934), the first university graduate employed, was appointed. David's early survey work was in the New England tin fields, which yielded the acclaimed first NSW Survey Memoir. Subsequently, he published memoirs on the Newcastle-Hunter Valley coalfields and adjacent Late Paleozoic glacial beds (Branagan, 2005). Paleontological work was undertaken by Etheridge from 1887. In 1894, he moved to the Australian Museum, and W.S. Dun (1868-1934) continued the paleontology working as a joint appointee of the Museum and Sydney University. Petrological work at the NSW Survey was undertaken by G.W. Card (1865-1943) between 1893 and 1929.

Fine work was done by NSW Survey geologists, including artesian water studies by Pittman, and later by E.J. Kenny (1895-1967) and C. Mulholland (1903-1984) in western NSW. Also notable were Carne's studies $(1903,1908)$ on coal and kerosene shale, E.C. Andrews' (1870-1948) geomorphology (Andrews, 1910), and geology of Broken Hill (Andrews, 1922), T.L. Willan's (1895-1940) Sydney region geological map (Willan, 1923) and L.J. Jones' (18821951) 1930s Newcastle Coalfield mapping. The NSW Survey, after the difficult World War II years, expanded rapidly in the late 1940s under Mulholland (Johns, 1976).

\section{Tasmania}

Official geological work began in 1859, when Charles Gould (1834-1893) was appointed. His extensive mapping, essentially alone, in the difficult western Tasmania terrain, established the island's Lower Paleozoic stratigraphy. As in the other colonies, Gould's scientific work was impeded by the official desire for prospecting, rather than thorough basic geological mapping. His contract was suspended in 1869. Following the discovery (1871) and development of large tin deposits at Mount Bischoff in the NW, and gold in the N, in 1882 Gustav Thureau (1831-1901) was appointed, initially as Inspector of Mines and later Geological Surveyor (until 1889) (McMullen 1996). However, R.M. Johnston (1843-1918), Government Statistician, rather than Thureau, prepared the classic Geology of Tasmania. Thureau was followed by Alexander Montgomery (1862-1933)). The Survey became firmly established under W.H. Twelvetrees (1848-1919) between 1899 and 1916, followed by local graduate C. Loftus-Hills (1885-1967) until 1923, who resigned after what he perceived as corrupt practice by his Minister. Work continued with A.H. Reid and P.B. Nye, and, briefly during World War II, with D. E. Thomas and S.W. Carey who made important advances on the geology and tectonics.

\section{The Victorian Survey resurrected}

Murray, Dunn and F.M. Krausé (1841-1918) were re-employed by the Victorian Government in 1870, under Brough Smyth, who directed the geologists' work toward mineral search. Through contact with the other colonies, Smyth compiled the first large geological map of Australia in 1875 showing some details of the inland region (Darragh, 1977). The Survey limped along until the late 1880s when James Stirling (d. 1908), and H. Herman (1875-1962) joined, working particularly in eastern Victoria.

The appointment of J.W. Gregory (1864-1932) as Director, in 1901, saw the Victorian Survey reactivated. A new mapping pattern began. Memoirs and Bulletins were established, and a new State Map was published. However, Gregory's reign was brief, resigning in 1904, E.J. Dunn becoming Director. He opened the Wonthaggi coalfield in Gippsland, and the Geological Museum, which played a useful role until the 1960s. Hyman Herman (Director, 1912-1920), encouraged the graptolite studies of R.A. Keble and H.S. Whitelaw, but Survey activities were restricted during World War I. Brown coal open-cut mining began in the Latrobe Valley in the 1920s, the geological work being undertaken under W. Baragwanath Jr. (1878-1966) (Director 1920-1943). At that time there was interest in possible oil occurrences in East Gippsland, and small discoveries were made near Lakes Entrance.

The Victorian Survey was badly affected by the 1930s depression. There was little fieldwork, except mapping for possible hydroelectricity power stations. Subsequently, D.E. Thomas (1904-1978) (Director 1946-1967) built up a dynamic Survey with twenty staff, embracing a wide range of expertise. In the mid 1960s systematic mapping at a scale of 1:250,000 began, and the first 1:1,000,000 geological map of the State was published in 1963. In this period economic oil resources were discovered offshore, under Bass Strait.

\section{Queensland}

Although Stutchbury and Clarke had worked in what was later the Colony of Queensland, no official survey occurred until gold was discovered at Gympie in 1866. Then separate Surveys were established in north and south Queensland in 1868, Richard Daintree being appointed Government Geologist for the North, and Christopher Aplin for the South. In 1872 Daintree went to London as Commissioner at the London Exhibition of Art and Industry, supervising an exhibition of Queensland rocks, minerals, fossils and photographs. He became Queensland Agent-General and presented a paper and the first 
geological map of Queensland to the Geological Society of London (1872). Daintree died in London in 1878. Aplin's appointment was short. He was followed, in 1875, by the explorer Augustus Gregory (1819-1905), who worked mainly on coal exploration, resigning in 1879.

In the north, R.L. Jack (1845-1921), previously with the Scottish Survey, replaced Daintree, in 1877, working from Townsville. When Gregory resigned, Jack became Government Geologist for the whole colony, working for the next twenty years, gaining professional acclaim, but with little thanks financially, or support with assistants. His Handbook of Queensland Geology (1886) included a new geological map of the colony. Jack, with Etheridge, published The Geology and Palaeontology of Queensland and New Guinea (two volumes with a new geological map: 1892). They had earlier (1881) published the detailed, extremely useful Catalogue of Geological Works on the Australian Continent which listed publications from many sources (Jack, 2008).

From late 1883 Jack was assisted by W.H. Rands (1861-1914), and, from 1887, by A. Gibb Maitland (1864-1951), who moved to Western Australia in 1896. Jack resigned in 1899 to undertake company work in China, and was succeeded by Rands, who, however, was retrenched in 1902.

Benjamin Dunstan (1864-1933), Assistant Geologist from 1897, from 1902 revived the Survey, with a staff of three. Reports and maps of mineral, gem, and coal fields continued, with a new State geological map (1903, revised 1908). His major publication was the Queensland Mineral Index (1913). Renewed interest in oil and natural gas exploration involved H.I. Jensen (1879-1966), formerly geologist for the Northern Territory, working in Queensland between 1917 and 1923. In 1923, Dunstan introduced aerial photography for his Survey's work, improvising equipment and photographing the newly discovered Mount Isa Pb-Zn field (NW Queensland). He also began geophysical investigations for mineral exploration. Dunstan's retirement in 1930 coincided with the Great Depression, and his successor, L.C. Ball (1877-1955), could only assist prospecting by establishing regional offices which remained maintained for many years.

Under A.K. Denmead (1955-1967), specialisation began. StateCommonwealth co-operation commenced with joint mapping for complete coverage of Queensland at 1:250,000 scale. A new state geological map, compiled in association with University of Queensland geologists, was published in 1953.

\section{Aerial, Geological and Geophysical Survey of Northern Australia}

An important development for Australian Geology was the formation in 1935 of the Aerial, Geological and Geophysical Survey of Northern Australia (AGGSNA), with Commonwealth and State financial involvement, seeking ore deposits $\mathrm{N}$ of the $20^{\text {th }}$ parallel. The brainchild of the industrialist W.H. Gepp (1877-1954), AGGSNA, with P.B. Nye (from the Tasmanian Survey) as Executive Officer, and J.M. Rayner (1906-1982) (NSW Survey) as Geophysical Consultant, was an important 'training ground' for the geologists and geophysicists who led the resurgence of geology in Australia in the post-World War II years. The earlier Imperial Geophysical Exploration Survey under Broughton Edge (1895-1953), which Gepp helped to develop in 1927, had indicated the likely value of geophysics in mineral exploration. AGGSNA was disbanded in 1940.

\section{Western Australia}

Official geological work in Western Australia began in 1847 with Ferdinand von Sommer (c. 1800-1849), after employment by the short-lived Western Australia Mining Company. Appointed to examine supposed coal occurrences, his contract was extended and he travelled widely, preparing eight reports, some fine maps and sections in less than a year. Glover and Bevan (2010) indicate that he lacked the qualifications he claimed but, in practice, his geological work displayed considerable knowledge and competence.

The Gregory brothers were investigating the geology from 1846. Augustus C. Gregory, (mentioned earlier) is best known. He made surveys in 1846 and 1848, discovering the Irwin River coal measures, and galena on the Murchison River, later the site of the Geraldine Mine. He led an important expedition in the Northern Territory in 1855-1856, before moving to Queensland where he was appointed Surveyor-General. Francis Gregory (1821-1888), also a surveyor, undertook expeditions in 1848 and 1861, and with his brother, Joshua (1815-1850), submitted a paper and Geological Map of Western Australia to the Geological Society of London (Gregory, 1848).

The Reverend Charles Nicolay (1815-1897) had a museum of geology at Fremantle from 1861, and acted as geological adviser when there was no official geologist. H.Y.L. Brown, Government Geologist (1870-1872), produced ten reports and three geological maps, but was sacked when the colony got into financial difficulties. The position was re-instated in 1882 when Irishman Edward Hardman (1845-1887) examined mineral resources in the Kimberley region, finding, in 1884-1885, strong indications of gold. Prospectors, following up, discovered the Halls Creek field, and a gold rush ensued. Ironically, the politicians voted not to renew Hardman's position just before the mineral boom began.

As the northern gold development occurred the Government Geologist position was re-established in 1887, and H.P. Woodward (1858-1917), then in South Australia under Brown, was appointed, with two assistants, B.H. Woodward (1846 -1916) and S. Göczel (1856-1918). This was a period of extraordinary prospecting and mining, including the discovery of gold at Coolgardie and Kalgoorlie, (Eastern Goldfields, $600 \mathrm{~km}$ E of Perth), and in the Pilbara region, to the N. Such discoveries put the now self-governing colony on a firm financial footing, leading to the formation of a Department of Mines in 1894 (Spillman, 1993).

Woodward resigned in 1895, being replaced by A. Gibb Maitland. He was invited to establish a Survey with assistant geologists, assayer, laboratory staff and a museum, achieving these goals by the end of 1897. Maitland's leadership, until retirement in 1926, saw half of the state systematically mapped at appropriate scales, generally in advance of prospecting. Ninety-one Bulletins were published 'covering almost all aspects of geological investigations known to the science at that time'.

H.W. Talbot (1874-1957), originally a surveyor, was a fine field geologist, despite no formal qualifications, noted for spending more time in the field than any other, 364 days in one particular year! Maitland said Talbot 'contributed more to the originally unknown parts of Western Australia than any other geologist'.

Also notable was E.S. Simpson (1875-1939), mineralogist and chemist, who served from 1897 to 1922 and was later Government Analyst. The survey was, at that time, in advance of most other state surveys in using petrology, notably by R.A. Farquaharson (18831959), in the Eastern Goldfields of WA. 
J.T. Jutson (1874-1959), initially with few qualifications, was another distinguished worker. His Outline of the physiographical geology (physiography) of Western Australia, (1914, later revised and re-issued several times), gained international regard.

Maitland's successors, Torrington Blatchford (1926-1934), Frank Forman (1934-1944), during the Depression, essentially 'marked time', the search for oil having little success. H.A. 'Matt' Ellis (19451961) began the revival of geological activities. He was followed by Joe Lord, who recruited geologists from overseas and formed specialist divisions, with a staff of thirty. Despite specialisation, Lord made the preparation of regional geological maps the Survey's first task, with detailed exploration and assessment of underground water. Lord's tenure coincided with the discovery of commercial oil at Barrow Island (1964), the beginning of iron ore exploitation in the Pilbara region, after lifting of the Commonwealth embargo (1960), the result of a belief that Australia had only limited iron resources, and the discovery of large Ni deposits at Kambalda in the Eastern Goldfields of WA.

\section{South Australia}

Significant geology was first done by the knowledgeable, but eccentric, Johannes Menge (1788-1852), who arrived in 1837 under contract to the South Australian Company. His work on Kangaroo Island, and good advice about seeking underground water for the Kingston settlement was ignored. He also noted that the island's limestone contained interesting fossils. Dismissed in 1838, Menge moved to mainland South Australia, searched for signs of mineralisation, collected minerals, and predicted commercial mining, which began with the opening of the Glen Osmond lead mine near Adelaide in 1841 (O’Neil, 1982). In 1844, Menge applied, without success, to be appointed Government Geologist.

The first publication on South Australian geology, Remarks on the Geology and Mineralogy of South Australia, appeared in 1846, written by Thomas Burr, Deputy Surveyor-General from 1839, then Mineral Surveyor (1846-1847), being replaced by James Trewartha (1847-1850). Benjamin Babbage (1815-1878) was appointed, in 1851, to 'make a Geological and Mineralogical Survey' of the Colony, but apart from a report on the Adelaide water supply (1852) did little geology, moving to other technical activities. From the late 1850s, the Rev J.E. Tenison Woods (1832-1889) carried out extensive work, mainly in the SE of the colony, describing the Mount Gambier volcanic region, metamorphic rocks and correctly identifying the mode of formation of the limestone caves of Naracoorte.

The South Australian Survey, recommended by Ralph Tate (18401901) of Adelaide University and the colony's Royal Society, was permanently established in December 1882, with the appointment of H.Y.L. Brown. Brown's previous experience in other colonies, Canada and New Zealand, fitted him admirably for the position, which he held until retirement in 1912, continuing as a Government consultant until his death. He was assisted by H.P. Woodward (1882-1887), then worked alone until 1906, when Henry Basedow (1881-1933) joined him for five years. Brown covered an enormous region, including not only South Australia but also the Northern Territory (Figure 7). A man of few words, Brown, put most of his geological findings on maps. He never complained about working conditions, surviving long periods when his camels travelled without water, and temperatures exceeded $100^{\circ} \mathrm{F}\left(38^{\circ} \mathrm{C}\right)$ for weeks at a time.

Brown published his first Geological Map of South Australia in 1883 (with numerous later editions), and one of the Northern Territory

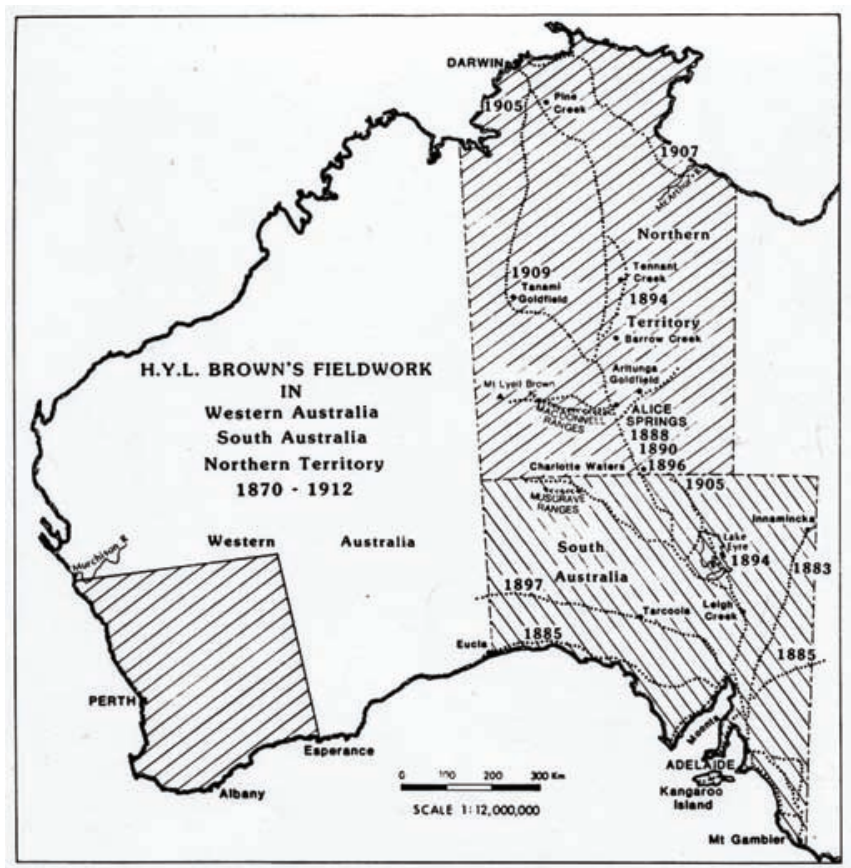

Figure 7 Fieldwork regions covered by Henry Yorke Lyell Brown, 1870-1912.

in 1898. He was followed by L. Keith Ward (1879-1964), a fine geologist who published many papers. He was supported by R. Lockhart Jack (1878-1964), son of R.L. Jack. Like other states, South Australia reinvigorated its Survey in the 1940s when S.B. (Ben) Dickinson became Government Geologist and Director of Mines. South Australia was probably the first State to begin formal mapping at 1:250,000 scale, a practice, instigated by Reg Sprigg (1919-1995), that quickly spread to the other states. Tom Barnes (1957-1970) followed Dickinson and encouraged diversification into the fields of geochemical exploration, seismic surveying, paleontology and engineering geology.

\section{Northern Territory}

Harald I. Jensen was the first appointed Geologist (1911-1916) when the Commonwealth Government took over administration of the Northern Territory in 1911, W.G. Woolnough (1876-1958) joining him the same year. They made a broad regional survey, concerned with the location of mineral resources. There had been earlier geological work in the Territory, by exploring expeditions who made general observations and collected rock and mineral specimens, and particularly by the Gregory Expedition previously mentioned. The first specifically geological report was written by Ralph Tate in 1882, and there were also papers published by Tenison Woods, Etheridge and Brown. After Jensen left, geological work in the Territory became rather ad hoc. A. H. Ellis was official Government Geologist briefly (1926-1928), assessing potential metal mines and underground water resources. Important gold production began at Tennant Creek in 1933, an occurrence noted by Brown as early as 1895. Commonwealth geologists were responsible for uranium discoveries in the 1950s, and a Territory Survey was established in 1970.

\section{Commonwealth Involvement}

In 1912, the Commonwealth, as guardian of what became known 
as Papua New Guinea, sent J.E. Carne of the NSW Geological Survey there to investigate coal deposits. He subsequently examined oil seeps, and noted copper mineralisation. Thus, realizing the potential, the same year the Commonwealth appointed Evan R. Stanley (18851924) as Government Geologist. Commonwealth interest in the possibility of oil occurrences began in 1915 when the English expert, Arthur Wade, was employed to assess the oil potential of Papua New Guinea, following which the Anglo-Persian Company was contracted to explore the territory. This was an unsuccessful operation, which ceased in 1929. Wade returned to Australia in 1924 to assess the possibilities within the continent.

The 'direct line' of a fully independent Commonwealth geological body began with the appointment of Walter G. Woolnough as Geological Adviser in 1927, assisted initially by Paul Hossfeld (18861967) in Canberra, and by the paleontologist, Frederick Chapman (1864-1943), and assistant, Irene Crespin (1896 -1980), in Melbourne. In the meantime Norman Fisher (1909 - 2009) became Government Geologist for New Guinea in 1934, joined in 1937 by Lyn Noakes (1914-1990). Then followed the formation of AGGSNNA (see above), the beginning of Commonwealth-state co-operation, although probably grudgingly on behalf of the States, who valued their autonomy.

Harold Raggatt (1900-1968) became assistant to Woolnough in 1940 and replaced him when he retired the following year. In 1942, the Commonwealth Mineral Resources Survey was formed under Raggatt, with P.B. Nye, Assistant Director; J.M. Rayner, Chief Geophysicist; and Fisher, Chief Geologist. This structure remained when the Survey became the Bureau of Mineral Resources, Geology and Geophysics (BMR) in 1946, the name changing to Australian Geological Survey Organization (AGSO) in 1992, (now Geoscience Australia). The range of work carried out by Commonwealth geologists has been considerable. Apart from those named, mention can be made of G.A.M. (Tony) Taylor (1917-1972), awarded the George Medal for his work during the Mount Lamington eruption (21 January, 1951), and the Estonian, Armin A. Öpik (1898-1983), whose paleontological work became legendary, though not everyone supported his contention that the Canberra region had suffered Late Paleozoic glaciation. Exploits of many Commonwealth geologists are discussed by Wilkinson (1996) in his history of Geoscience Australia.

There was other important Commonwealth geological activity. In 1916, the Institute of Science and Industry was established, to undertake research regarded essential for Australia's prosperity. This included alunite availability, and gold deposits at Bendigo, studied by F.L. Stillwell (1888-1963) from 1916-1919. In the 1920s the Institute was re-organised as the Commonwealth Scientific Industry Research Organisation (CSIRO). Some of its early work was directed towards mineral beneficiation, through Stillwell. In 1935, A.B. Edwards (1909-1960) joined Stillwell, studying ore microscopy, publishing Textures of the Ore Minerals and their Significance (1948). Work of international importance was carried out by this group, including the pioneer study by George Baker (1908-1975) of tektites, formed during entry through the Earth's atmosphere, which attracted the attention of NASA, when investigating satellite re-entry problems. Later geological activities within CSIRO, yet to receive historical evaluation, include coal and hard rock petrology, and marine geology within the Division of Exploration and Mining. The Baas-Becking Laboratory, supported by Commonwealth organizations and mineral industry bodies was established in the early 1950s, doing important bio-geological research.

\section{Academic Geologists}

Australian Universities, from the foundations of Sydney (1852) and Melbourne (1853), have played a continuing role in both the education of Australian geologists and in research.

\section{University of Sydney}

Geology became a formal subject from 1866 under Alexander M. Thomson (1841-1871). He died after a lung infection picked up from fieldwork at Wellington Caves, and was followed by Archibald Liversidge (1846-1927) (Figure 8) with expertise in chemical mineralogy. He created, in 1888, the long-lived Australasian Association for the Advancement of Science (AAAS), later renamed Australian and New Zealand Association for the Advancement of Science (ANZAAS) (MacLeod, 2009). The AAAS brought together Australasia's geologists (and other scientists) for regular meetings, in different centres, to present their research, become personally acquainted, make friendships (or not), argue about concepts, matters previously only possible by correspondence across the vast distances separating their work places. The Association's annual reports remain valuable sources of information, particularly the subcommittee reports on glaciation, stratigraphy and structural geology (Vallance and Branagan, 1988).

Between 1882 and 1890, William J. Stephens (1829-1890) taught regional geology and paleontology. Stephens' sudden death resulted in the appointment, from the NSW Survey, of Edgeworth David (Figure 9), who was destined to become the doyen of Australian geology over the next forty years. His life was legendary, including Antarctic and military experience, culminating in completion of his Geological Map of the Commonwealth (1932) (Figure 10), accompanied by a superb summary of the geology,

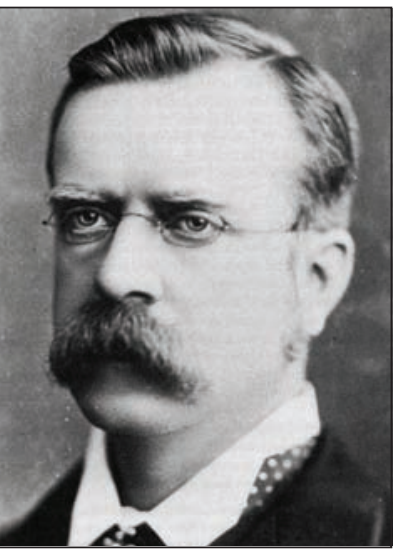
Figure 8 Archibald Liversidge, mineralogist and chemist, founder of the Australasian ment of Science (1888).

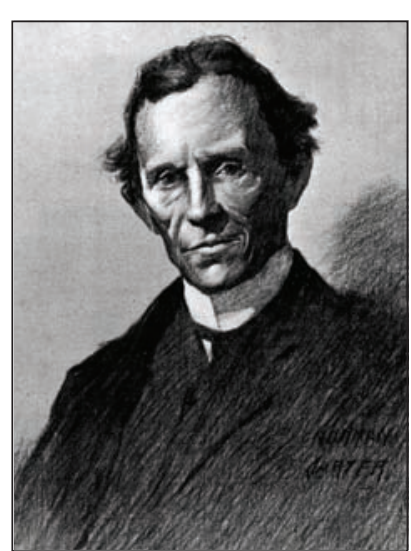

Figure 9 T.W. Edgeworth David, 'doyen' of Australian Geologists, by his friend Norman Carter (1909). Association for the Advance-

written in just a few weeks. David's contribution to Australian geology, through teaching, research, public appearances and popular writing, is unequalled (Branagan, 2005).

David's students contributed in almost every region of Australia. They included E.C. Andrews, W.G. Woolnough, Douglas Mawson (1882-1958), W.R. Browne (1884-1975), L.A. Cotton (1880-1963), 


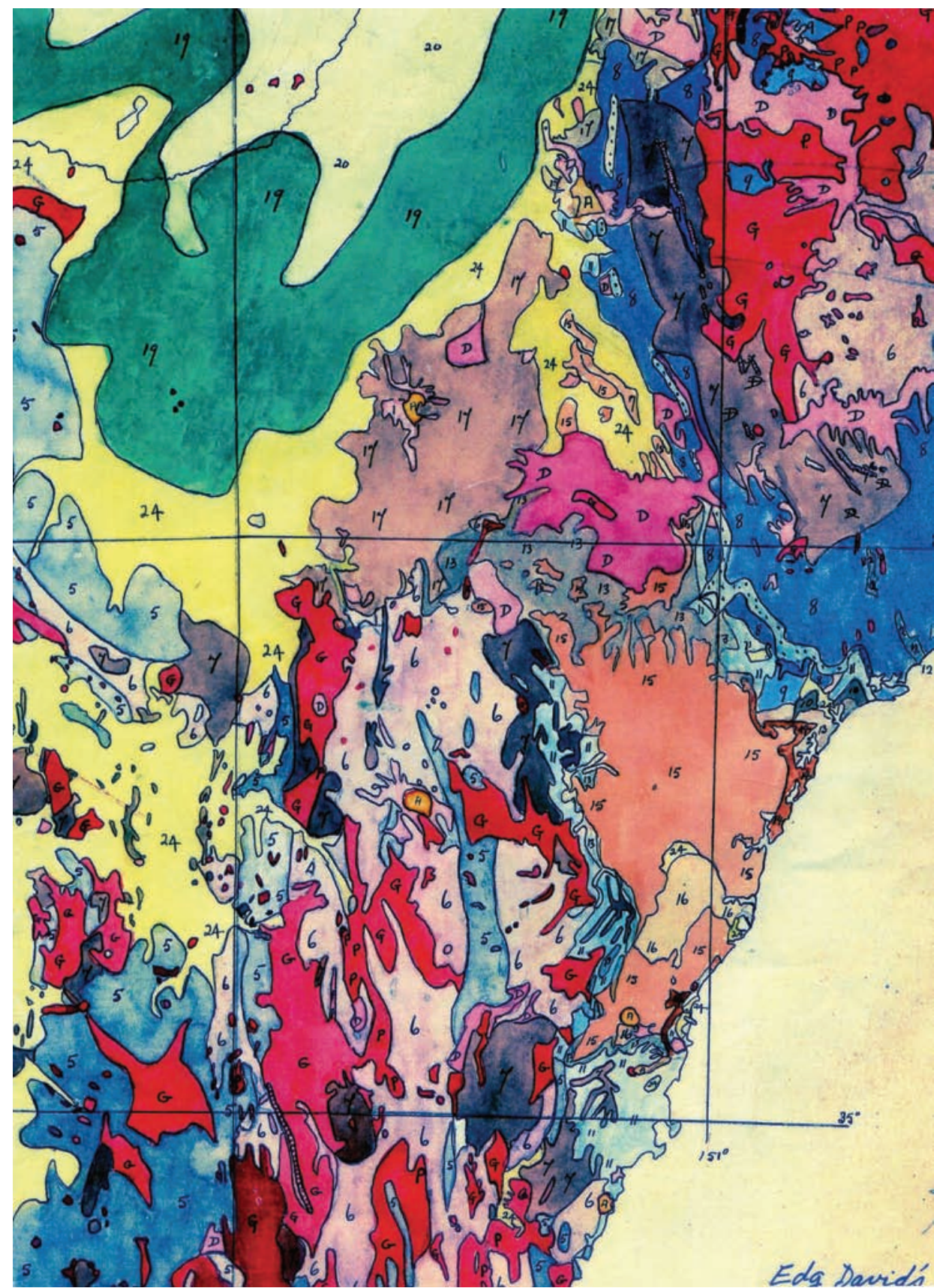

Figure 10 Portion of Edgeworth David's draft for the Geology of the Commonwealth Map (1929).

T. Griffith Taylor (1880-1963), Frank Debenham (1883-1965), M. Aurousseau (1891-1983), W.N. Benson (1885-1957), and H.G. Raggatt. When David retired in 1924, Cotton, a geophysicist, was appointed, remaining until his retirement in 1948. The 'David Era' ended with the appointment in 1949 of Englishman Charles E. Marshall (1908 -1992), coal petrologist-cum-engineering geologist.

\section{Melbourne}

In 1853, Irish-born Frederick McCoy (1817-1899), became Foundation Professor of Natural Science, including mineralogy, practical geology and paleontology. McCoy was more interested in museums than teaching, building up a fine collection, and continuing paleontological research, while students complained they never had a geology field excursion. McCoy's contemporary, Ferdinand von Mueller (1825-1896) (at the Melbourne Botanical Gardens), known essentially as a botanist, made important paleobotanical studies, mainly on Tertiary flora. McCoy clashed with Selwyn, the Survey Director, over mining matters. J.W. Gregory (18641932) replaced McCoy. It proved a dramatic change, Gregory enthusing students to go into the field, and leading by example. Although Gregory stayed only four years he did more work than most professors undertake in ten or twenty years. He is remembered for his summer journey with students into what he called the 'Dead Heart' of Australia, a term which caught the imagination of ordinary Australians (Branagan and Lim, 1984). Not content with teaching and fieldwork, as mentioned above, Gregory accepted appointment as Director of the Geological Survey of Victoria, but moved to Glasgow in 1904 where his notable reputation was sustained (Leake, 2011).

Ernest Skeats (1875-1953) followed Gregory, building a strong a reputation for petrology, with students such as Stillwell and H.C. Richards (later the first Professor of Geology at Queensland University). Edwin Sherbon Hills (1906-1986), another of Skeats's students, replaced him in 1944, and is remembered for his classic Outlines of Structural Geology (translated into many languages). He became Foundation President of the Geological Society of Australia in 1952.

\section{Adelaide University}

At its foundation (1874), among its first appointments (Natural Science) was Ralph Tate, a student of the Royal School of Mines, London. Tate quickly began researching the local geology and established the Royal Society of South Australia. In 1877, his examination of glacial evidence at Hallett Cove, near Adelaide, revived interest in this subject, evidence having been recorded in 1859 by the visiting Alfred Selwyn. Tate's geology ranged from Precambrian to Tertiary (the latter perhaps his greatest contribution to Australian geology). Tate was a 'big' man in many ways, enjoyed student company, and is said to have always travelled with a cask of beer on field trips (Alderman, 1967).

When Tate died the University did not appoint another professor, but two lecturers (probably cheaper!), Walter Howchin (18351937) and W.G. Woolnough. The latter returned to Sydney in 1904, and Douglas Mawson was appointed in his place (Ayres, 1999). However, Mawson's long period of Antarctic exploration and military duties saw the teaching largely left to Howchin until 
1920, with some short-term appointments. As a Methodist minister, Howchin preached in country places at weekends, and, in conjunction, undertook fieldwork, continuing this practice for ten years following retirement. Howchin's achievements in South Australian geology at least equalled those of H.Y.L. Brown, and included his recognition of Cambrian (now Neoproterozoic) glaciation, which gained him international recognition (Cooper, 2000).

On Howchin's retirement, Mawson became professor and was joined by Cecil T. Madigan (1889-1947) as lecturer. Both physically big men and with strong personalities, they did not always agree, and Mawson made life difficult for his subordinate. The latter, however, gained fame in the early 1930s making the first successful crossing of the formidable Simpson Desert from Northern Territory to Queensland by camel (Twidale et al., 1990).

In 1949 the Geology School was divided, Mawson teaching General Geology, with Eric A. Rudd (1910-1998) appointed for Economic and Mining Geology (the first in Australia). Rudd raised funding through good relations with industry. The brilliant Martin Glaessner (1906-1989) revived South Australian studies in paleontology and stratigraphy when appointed in 1950, culminating in the study of the Ediacara fauna, discovered in 1947 by Reginald (Reg) Sprigg (Weidenbach, 2008). Photos of such fossils are included in Figure 7 of Gehling and Droser (2012).

\section{Younger Universities}

The University of Tasmania (Hobart, 1893), initially had only sporadic geology instruction. Geology became established in 1946 when S. Warren Carey (1916-2004) (Figure 11) was appointed professor. Carey's international reputation came from his controversial ideas on tectonics, involving the notion of Earth expansion.

Geology at Queensland University began in 1911 (Hill, 1981) and, prior to World War II, there were four staff: H.C. Richards (18841947), responsible for setting up the Great Barrier Reef (Research) Committee, A.B. Walkom (paleontologist; 1913-1920), W.H. Bryan (1891-1966) from 1920, and F.W. Whitehouse (1900-1973) from 1926. All had fine reputations for research and teaching, covering a wide range of topics. The breadth of research was greatly

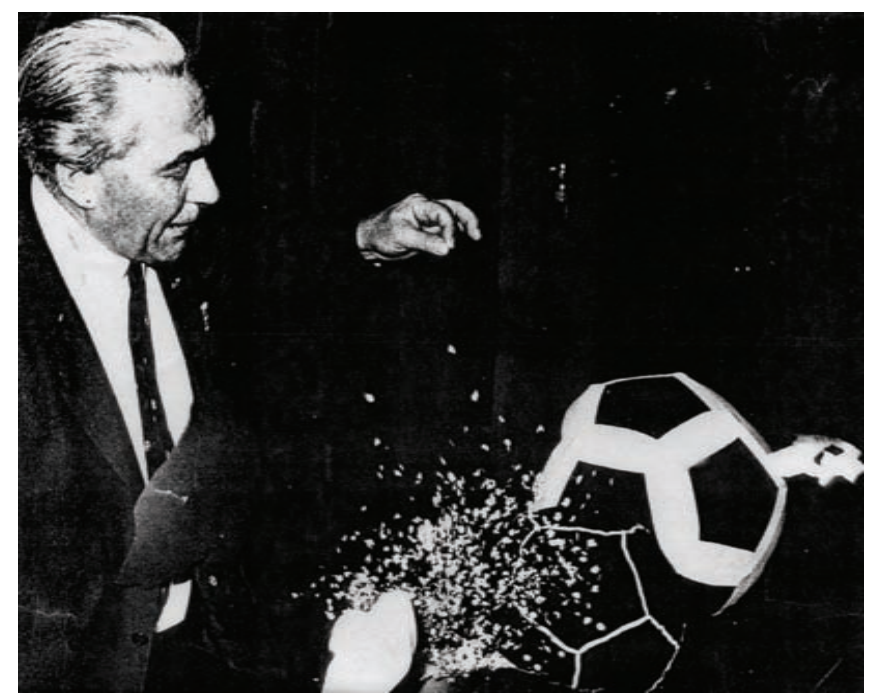

Figure 11 S.W. Carey 'illustrates' his idea about Earth Expansion, at the ANZAAS Congress, Port Moresby, Papua New Guinea, 1970. supplemented by the appointment of Dorothy Hill at the end of the war (see below).

The University of Western Australia (Perth) opened in 1913, when W.G. Woolnough was appointed and Marcel Aurousseau assisted. Edward de Courcy Clarke (1880-1956) and Rex Prider followed (Glover, 2003; Glover and Bevan, 2010).

New England College of Sydney University, (Armidale, NSW), established 1938, became the independent University of New England in 1954. A.H. Voisey, initially the sole lecturer, continued as Foundation Professor. He was an inspirational teacher, enthusing students to undertake detailed studies of northeastern New South Wales, a theme continued by his successors. He took up the foundation chair in Geology when Macquarie University was opened in 1967, and built up a fine school, including geology, geomorphology and geophysics.

The Australian National University was founded as a research body in 1946, the Research School of Earth Sciences becoming outstanding, with researchers such as Ted Ringwood. Canberra University College, from 1930 an adjunct of the University of Melbourne, introduced science studies in 1958. Strong teaching and research began when undergraduate studies were introduced in the amalgamated National University in 1960 under Foundation Professor D.A. Brown (d. 2010) (Rickard, 2010).

From its beginning the University of New South Wales, initially the NSW University of Technology (1949), was linked to mining education. Early teachers/researchers were L.J. Lawrence from 1951, F.C. Loughnan from 1954, and C.T. McElroy (stratigraphy), all exservice class-mate graduates from Sydney University. McElroy became Director of the NSW Geological Survey in 1967. Another early teacher was the geochemist, Leo Koch (Lawrence et al., 2003).

Monash University (Melbourne) founded 1958, quickly built up a fine reputation for teaching and research. Geology at Newcastle University was 'inherited' from the 1890s School of Mines, then as a college of the then University of Technology, 1952, becoming independent in 1960 (Nashar, 1977).

\section{The 1920s: Women Geologists become visible}

Despite women in Australia achieving the right to vote in 1902, the geological profession remained essentially closed to them for many reasons. As late as 1976, some mining companies refused to allow underground visits by women.

An early would-be geologist was the eccentric, long-lived amateur, Georgina King (1845-1932). She attracted no followers. Whilst Edgeworth David, at Sydney University, from the 1890s, encouraged women students, he was opposed by administrators when making appointments, even at junior teaching levels. One was Fanny Cohen (1887-1975) who published on Broken Hill azurite crystals. She later became a noted headmistress encouraging several generations of students into science. Marie Bentivoglio, scholarship winner (1918), studied mineralogy, and then moved to geographical problems in the newly created Department of Geography under T. Griffith Taylor, where she was, in 1929, acting Professor, before becoming a crystallographer in North America. Also at Sydney University, Ida Brown (1922-1950), a petrologist, worked on the far south coast of New South Wales (1928-1933) before switching to paleontology in 1934, after the death of W.S. Dun. Her fossil studies achieved 
widespread acknowledgement. Petrologist Germaine Joplin studied contact alteration zones and published well-received textbooks. Despite nominations, she was never elected to the Australian Academy of Sciences. Other Sydney women from the period included Florrie Quodling, crystallographer; Alma Culey, sedimentologist (Branagan and Holland, 1985). Maren Krysko (d. 2010) was a respected teacher at the University of New South Wales.

From Melbourne University came a plethora of paleontologists: Kate Sherrard (1898-1975), graptolite studies, assistant lecturer (early 1920s) and left-wing activist; Isabel Cookson (1893-1973), paleobotanist from 1929, studied Lower Paleozoic vascular land plants and Tertiary fossil plants, and applied paleobotany to oil search. Irene Crespin (1896-1980) (Figure 12), influenced by both Charles Fenner and Frederick Chapman (Commonwealth Paleontologist), worked in

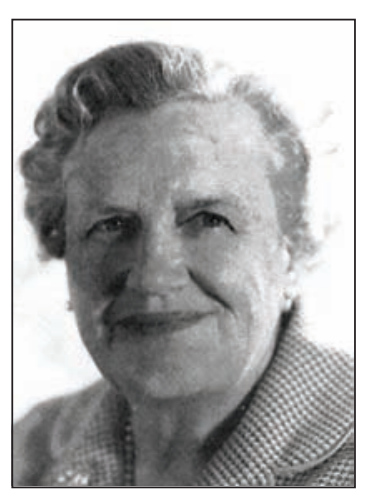

Figure 12 Irene Crespin, Commonwealth paleontologist, worked in Melbourne, then Canberra.

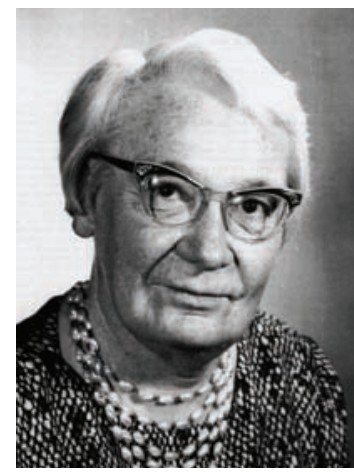

Figure 13 Dorothy Hill, FRS, Paleontologist, President of the Australian Academy of Science and the Geological Society of Australia. the Geological Survey of Victoria, then as Chapman's assistant, succeeding him in 1936, but at half his salary (!). She subsequently moved to Canberra where she worked with W.G. Woolnough (Crispen, 1972). Adelaide University graduate, Nell H. Ludbrook (19071995), undertook post-graduate studies in England, returning in 1935 to Canberra, as Assistant to Woolnough and later was with the South Australian Survey (1952-1967). She showed that paleontology could be useful to the resources industry and the $P$. Ludbrookiae zone in the Eromanga and Surat basins honours her work (see Cook, 2012). Mary Wade (1928-2005) contributed to the understanding of the Ediacaran fauna (Turner, 2007).

Best remembered of the women geologists, is Dorothy Hill (1907-1997) (Figure 13) of Queensland University, who after post-graduate studies in Cambridge (1930-1938), worked at CSIR to 1943, then at Queensland University where she was later Head of School. Hill gained an FRS mainly for her work on Paleozoic corals, was elected to the Australian Academy of Science, of which she was President in 1970 (Campbell and Jell, 1998).

Apart from the South Australian Geological Survey, which employed Maud McBriar in 1948, E.N. Dolling (1950-1952) and Nell Ludbrook from 1952, not until the 1960s did the other State surveys employ female geologists. Final acceptance can be noted by the then relatively early elections of Nell Ludbrook (1968-1969) and Dorothy Hill (19731975) to the presidency of the Geological Society of Australia.

\section{Schools of Mines, Museums and Geological Societies}

Technical Colleges and Schools of Mines have contributed to geology, largely in teaching, often being influenced by specific local mining activity. Museums have collected and archived important collections, perhaps most notably in paleontology and mineralogy.

\section{Schools of Mines}

Derived from the various Mechanics Schools of Arts of the 1830s, Schools of Mines and Technical Colleges provided good geological training for potential mine managers and technicians but there was little opportunity for research. Initially located in mining towns, notably in Victoria, later there were important technical colleges in some cities, e.g., Sydney University established a School of Mines in 1892 through the joint efforts of Edgeworth David and Archibald Liversidge (Branagan and Holland, 1985).

The Ballarat School of Mines was established in 1870, under Ferdinand M. Krause (Perry 1984). Others included Bendigo (1873) (Cusack, 1973), Castlemaine, where Thomas Sergeant Hall (18581915) made outstanding studies of Ordovician graptolites, including suggesting international correlations. Melbourne Working Men's College included Hall's research colleague G.B. Pritchard (18691956), who had 33 hours of lectures per week, plus weekend excursions! In other colonies were Kalgoorlie (Western Australia), Adelaide (1892), Zeehan (Tasmania) (1892), Charters Towers and Gympie (Queensland, from 1901), while technical colleges in New South Wales (from the 1880s) included teachers/researchers such as C.A. Süssmilch (1875-1946) (Newcastle) and J. Milne Curran (1859-1928) (Sydney).

\section{Museums}

Over the years Museums have made important research contributions, perhaps most notably in paleontology, as told in various histories (e.g., Strahan, 1979). Notable staff include the paleontologists, Felix Ratte (d. 1890), Robert Etheridge, A.B. Walkom and Harold Fletcher (1903-1996), the mineralogists, Charles Anderson (1876-1944) and Oliver Chalmers, at the Australian Museum, Sydney; F. Chapman, E.D. Gill and the petrologist, D.J. Mahony, at the National Museum, Melbourne; Charles De Vis (1829-1915) and Heber Longman at the Queensland Museum. Western Australia Museum staff made significant meteorite studies. The South Australian Museum has important mineral collections, while Robert Bedford (1874-1951) at his small museum at isolated Kyancutta, South Australia, did important research on Archaeo-cyathidae. The Tasmanian Museum has an extensive Antarctic collection. Other smaller museums (e.g., Canowindra fossil fishes) contain important historic and scientific collections.

\section{The Societies}

Learned societies have facilitated discussion amongst geologists and ideas to be debated, as seen above, but space does not allow discussion of the various societies devoted to the geological sciences. For histories of the Geological Society of Australia see Cooper and Branagan (1994); for the Australasian Institute of Mining and Metallurgy (Dew, 1993). Other newer bodies include The Australian Institute of Geoscientists, Australian Society of Exploration Geophysicists, Australian Petroleum Exploration Association and Australian Geomechanics Society. 


\section{Company Geologists and Research}

While the history of Australian mining has an increasing literature (Blainey, 1963; Raggatt, 1968; Trengrove, 1976 and the Journal of the Australasian Mining History Association), there are few detailed studies of the geologists who have contributed to the search and development of the major ore bodies, except for Glasson and Rattigan (1990). Records of this work are in the papers of various mining companies, and are often difficult to access. Haddon King (1989) illustrates this problem, as of 46 references to his own work 36 are 'unpublished' company records. This field of research offers many rewards, but can also be very frustrating.

In the field of Engineering Geology, for which Australia has a proud record, little history has been recorded. The establishment of the Snowy Mountains Scheme, diverting water from the SE-flowing Snowy River to the westerly flowing tributaries of the Murray River in the late 1940s (Wilkinson, 1996) saw the beginning of modern engineering geology work in Australia, with pioneering conceptual work directed by Dan Moye (1920 - 1975), then being taken up by other later engineering projects in Australia and overseas by Australian engineering geologists.

\section{Acknowledgements}

Particular thanks are due to David Oldroyd and Barry Cooper who pointed out initial inaccuracies and omissions and suggested significant improvements to this paper. Keith Johns, responsible for the idea and then completion, against the odds, of his important compilation of the history of Australian Geological Surveys (1976), was an inspirational source. Keith Scott's advice also greatly improved the paper.

\section{References}

For many of the geologists noted see the Australian Dictionary of Biography (18 volumes to date) published by Melbourne University Press, Melbourne. See also Guide to the Archives of Science in Australia: Records of Individuals (compiled and edited by Gavan McCarthy and D.W. Thorpe, 1991) and obituaries in the Historical Records of Australian Science (earlier Records of the Australian Academy of Science), and in the journals of the various State Royal Societies.

Alderman, A., 1967, The Development of Geology in South Australia: Australian Academy of Science, Records, v.1, pp. 30-52.

Andrews, E.C., 1910, Geographical unity of Eastern Australia in late and Post Tertiary time: Royal Society of New South Wales, Journal and Proceedings v. 44, pp. 420-480.

Andrews, E.C., 1922, Geology of the Broken Hill District: Geological Survey of New South Wales, Memoir 8.

Aurousseau, M. (translator), 1968, The Letters of F.W. Ludwig Leichhardt: 3 vols: Hakluyt Society, Second Series No. CXXXV, Cambridge.

Ayres, P., 1999, Mawson: A Life: Miegunyah Press, Melbourne.

Banks, M.R., 1990, Geology, in Plomley, B., Vornell, C. and Banks. M. (eds), Francois Peron's Natural History of Maria Island, Tasmania: Records of the Queen Victoria Museum, v. 99. Launceston, Tasmania.

Blainey, G., 1960, Mines in the Spinifex: The Story of Mt Isa Mines: Angus and Robertson, Sydney.

Blainey, G, 1963, The rush that never ended: Melbourne University Press, Melbourne.

Branagan, D.F., 1986, Strzelecki's Geological Map of southeastern Australia: an eclectic synthesis: Historical Records of Australian Science v. 6, pp. 375-393.

Branagan, D.F., 2005, T.W. Edgeworth David: A Life: National Library of Australia, Canberra.
Branagan, D.F. and Holland, H.G. (eds), 1985, Ever Reaping Something New: A Science Centenary: University of Sydney, Sydney.

Branagan, D.F. and Lim, E, 1984, J.W. Gregory, Traveller in the Dead Heart: Historical Records of Australian Science, v. 6, 14 pp.

Branagan, D.F. and Moore, D.T., 2008, W.H. Fitton's Geology of Australia's Coasts, 1826: Historical Records of Australian Science, v.19, pp.1-51.

Branagan, D.F. and Townley, K.A., 1976, The Geological Sciences in Australia - A brief Historical Review: Earth Sciences Reviews, v.12, pp. 323 346.

Campbell, K.S.W. and Jell, J.S., 1998, Dorothy Hill 1907-1997: Historical Records of Australian Science, v. 12, pp. 205-228.

Carne, J.E., 1903, The Kerosene Shale Deposits of New South Wales: NSW Geological Survey, Memoir 3.

Carne, J.E., 1908, Geology and Mineral Resources of the Western Coalfield: NSW Geological Survey, Memoir 6.

Cook, A.G., 2012, Cretaceous faunas and events, northern Eromanga Basin, Queensland: Episodes (this volume).

Cooper, B.J. and Branagan, D.F. (eds), 1994. Rock me hard, rock me soft: The Geological Society of Australia, Sydney.

Cooper, J. (compiler), 2000, Records and Reminiscences: Geosciences at the University of Adelaide 1875-2000: University of Adelaide, Department of Geology and Geophysics.

Crespin, I., 1972, Recollections on the Growth of Commonwealth interest in the Geological Sciences: Records of the Australian Academy of Science, v. 2, pp. 29-46.

Cusack, F., 1973, From Canvas to Campus. A history of the Bendigo Institute of Technology: Hawthorn Press, Melbourne.

Darragh, T.A., 1977, The First Geological Maps of the continent of Australia: Journal of the Geological Society of Australia, v. 24, pp. 279-305.

Darragh, T.A., 1987, The Geological Survey of Victoria under Alfred Selwyn, 1852-1868: Historical Records of Australian Science, v. 7, pp. 1-25.

Darragh, T.A., 2000, Robert Brough Smyth: His Early Years as revealed by his Correspondence with Adam Sedgwick: Historical Records of Australian Science, v. 13, pp. 19-42.

Day, A.A., 1966, The Development of Geophysics in Australia. Royal Society of New South Wales, Journal and Proceedings, v. 100, pp. 33-60.

Dew, J.M., 1993, Mining People: A Century: The Australasian Institute of Mining and Metallurgy, Publication Series No. 1/93.

Glasson, K.R. and Rattigan, J.H., 1990, Geological Aspects of the Discovery of some Important Mineral Deposits in Australia: The Australasian Institute of Mining and Metallurgy, Monograph 17.

Gehling, J.G. and Droser, M.L., 2012, Ediacaran stratigraphy and the biota of the Adelaide Geosyncline, South Australia: Episodes (this volume).

Glover, J., 2003, Geological Journeys: from Artifacts to Zircon: Geological Society of Australia (Western Australia Division).

Glover, J. and Bevan, J., 2010, The Forgotten Explorers: Pioneer geologists of Western Australia, 1826-1926: Hesperian Press, Victoria Park, WA.

Gregory, J.W. and Gregory, F.T., 1848, Remarks to accompany a geological map of Western Australia. Geological Society of London, Quarterly Journal, v. 4, p. 142.

Hill, D., 1981, The first fifty years of the Department of Geology of the University of Queensland: Department of Geology, University of Queensland, v. 10.

Jack, F., 2008, Putting Queensland on the map: The life of Robert Logan Jack, geologist and explorer: University of New South Wales Press, Sydney.

Johns, R.K. (ed), 1976, History and Role of Government Geological Surveys in Australia: Government Printer, Adelaide.

Jukes, J.B., 1850, A Sketch of the Physical Structure of Australia so far as it is at present known: T. and W. Boone, London.

King, H., 1989, The Rocks Speak: Essays in geology - some personal responses of a willing listener: The Australasian Institute of Mining and Metallurgy, Monograph 15.

Lawrence, L.J., Ward, C.R., Neef, G. and Rickwood, P.C., 2003, Fifty Plus: A history of Geology at the University of New South Wales 1949-2002: School of Biological, Earth and Environmental Sciences, University of New South Wales, Sydney.

Leake, B., 2011, John Walter Gregory: Geological Society of London, Memoir 34.

Leichhardt, L., 1855, Beitráge zur Geologie von Australien von L. Leichhardt, herausgaben von H. Girard: Abhandlung Naturforsche Gesellschaft, v. 3,62 pp. 
Leichhardt, L., 1867-68, Notes on the Geology of parts of New South Wales and Queensland made in 1842-43, (Ulrich, G.H. (translator), Clarke, W.B. (ed)): Australian Almanac, 1867, pp. 29-55 and 1868, pp. 29-52.

MacLeod, R., 2009, Archibald Liversidge FRS: Imperial Science under the Southern Cross: Royal Society of New South Wales and University of Sydney Press, Sydney.

McMullen, G.L., 1996, “An Able Practical and Scientific Man”: Gustav Adolph Hugo Thureau, German-trained Mining Geologist: Historical Records of Australian Science, v. 11, pp. 149-177.

Mayer, W., 2005, Deux géologues francais en Nouvelle-Hollande (Australie): Louis Depuch et Charles Bailly, membres de l'expédition Baudin (18011803) : Travaux du Comité Francais D’Histoire de la Géologie (COFRIGH`EO), troisieme s'erie, T. XIX, NO. 695-112.

Mayer, W., 2007, The quest for limestone in colonial NSW, 1788-1825, in Wyse Jackson, P.N. (ed), Four Centuries of Geological Travel: The Search for knowledge on Foot, Bicycle, Sledge and Camel: Geological Society of London, Special Publication 287, pp. 325-342.

Mayer, W, 2009, Geological Observations by the Rev. C.P.N. Wilton (17951859) in New South Wales and his observations on the relations between Geology and Religion, in Martina Köebl-Ebert (ed), Geology and Religion Historical Views of an Intense Relationship between Harmony and Hostility: Geological Society of London, Special Publication 310, pp.197209.

Moyal, A., 2002, The Web of Science: The Scientific Correspondence of the Rev. W.B. Clarke, Australia's Pioneer Geologist: Australian Scholarly Publishing, Melbourne, 2 vols.

Nashar, B., 1977, The First Twenty-five Years in Department Geology Newcastle University College and the University of Newcastle, N.S.W.: The University of Newcastle, New South Wales. 70 pp.

Nicholas, F.W. and Nicholas, J.M., 1989, Darwin in Australia: Cambridge University Press, Cambridge.

Oldroyd, D., 2007, In the Footsteps of Thomas Livingstone Mitchell (17921855): soldier, surveyor, explorer, geologist, and probably the first person to compile geological maps in Australia, in Wyse Jackson, P.N. (ed), Four Centuries of Geological Travel: The Search for Knowledge on Foot, Bicycle, Sledge and Camel: Geological Society of London, Special Publication 287, pp. 343-373.

O'Neil, B., 1982, In search of Mineral Wealth: The Geological Survey of South Australia and Department of Mines 1882-1944: Department of Mines and Energy, South Australia, Special Publication No. 2.

Paszkovski, L., 1997, Sir Paul Edmund de Strzelecki: Arcadia Scholarly Publishing, Melbourne.

Pemberton, P.A., 1986, Pure Merinos and Others: The "shipping lists" of the Australian Agricultural Company: Australian National University Archives of Business and Labour, Canberra.

Perry, W., 1984, The School of Mines and Industries Ballarat: A history of the first one hundred and twelve years, 1870-1982: The School of Mines and Industries, Ballarat.

Raggatt, H.G., 1968, Mountains of Ore: A History of Australian Mining: Landsdowne Press, Melbourne.

Rickard, M. (compiler), 2010, Geology at ANU (1959-2009), 50 years of History and Reminiscences: Australian National University, Canberra.
Roderick, C., 1988, Leichhardt, the Dauntless Explorer: Angus and Robertson, North Ryde, New South Wales.

Scott, T.W.H., 1824, Sketch of the Geology of New South Wales and Van Diemen's Land: Annals of Philosophy (new series), v. 7, pp. 461-462.

Scott, T.W.H., 1831, Geological remarks on the vicinity of Swan River and Isle Buache or Garden Island, on the coast of Western Australia: Geological Society of London, Proceedings, v. 1, pp. 330-331.

Spillman, K., 1993, A Rich Endowment: Government and Mining in Western Australia 1829-1994: University of Western Australia, Perth.

Strahan, R, 1979, Rare and Curious specimens: An Illustrated History of the Australian Museum 1827-1979: The Australian Museum, Sydney.

Strzelecki, P.E. 1845, Physical Description of New South Wales and Van Diemen's Land: Longman, London.

Thorpe, N.J., 1953, The history of the Botany water supply: Sydney Water Board Journal, v. 3, pp. 74-86.

Trengrove, A., 1976, Adventure in Iron: Hamersley's First Decade: Stockwell Press, Clayton,Victoria.

Turner, S., 2007, Invincible but mostly invisible: Australian women's contribution to geology and palaeontology: Geological Society of London, Special Publications, v. 281, pp. 165-202.

Twidale, C.R., Parkin, L.W. and Rudd, E.A., 1990, C.T. Madigan's contributions to geology in South Australia: Royal Society of South Australia, Transactions, v. 114, pp. 157-167.

Vallance, T.G., 1975, Presidential Address: Origins of Australian Geology: Linnean Society of New South Wales, Proceedings, v. 100, pp. 13-43.

Vallance, T.G., 1977, John Lhotsky and Geology, in Kruta,V., Whitely, G.P., Vallance, T.G., Willis, J.H. and Wakefield, N.A.(eds), Dr. John Lhotsky: The Turbulent Australian Writer, Naturalist and Explorer: Australia Felix Literary Club, Melbourne.

Vallance, T.G., 1981a, The start of Government Science in Australia: A.W.H. Humphrey, His Majesty's mineralogist in New South Wales: Linnean Society of New South Wales, Proceedings, v. 105, pp. 107-146.

Vallance, T.G., 1981b, 'The Fuss about Coal', in Carr, D.J. and Carr, S.G.M. (eds), Plants and Man in Australia: Academic Press, Sydney, pp. 136176.

Vallance, T.G. and Branagan, D.F., 1988, The Earth Sciences: Searching for Geological order, in Macleod, R. (ed), The Commonwealth of Science: ANZAAS and the Scientific Enterprise in Australasia 1888-1988: Oxford University Press, Melbourne, pp. 130-146.

Von Buch, L, 1814, Einige bemerkungen über die geognostiche Constitution von Van Diemen's Land: Magasin der Gesellschaft Naturforschung Freunde zu Berlin, vi, pp. 234-240.

Weidenbach, K., 2008, Rock Star: The Story of Reg Sprigg-an outback legend: East Street Publications, Adelaide.

Wilkinson, R., 1996, Rocks to Riches: The story of Australia's national geological survey: Allen and Unwin, Sydney.

Willan, T.L. 1923, The geology of the Sydney Region, in Guide-book to the excursion in the Sydney District: Proceedings Pan-Pacific Congress, Australia, pp. 22-25. (see also Geological Map of Sydney District, NSW Geological Survey, 1925.)

Wilton, C.P.N., 1829, A volcano in Australia: The Australian Quarterly Journal of Theology, Literature and Science, No. IV, pp. 382-385.

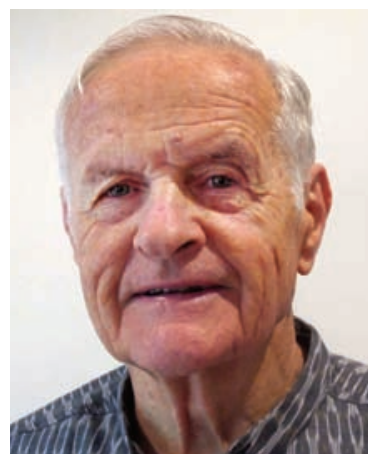

David Branagan is an Honorary Research Associate in the School of Geosciences, University of Sydney, where he was a teacher and researcher between 1959 and 1989, mainly in engineering geology and photo-interpretation, and consultant to various government and commercial organizations. He has published a number of books and papers on aspects of Australian geology and its history. He was foundation editor of the Australian Geologist, (1974-1984) and is an Honorary Life Member of the Geological Society of Australia. He was President of the International Commission on the History of the Geological Sciences (1992-1996) and was awarded an Honorary DSc by the University of Sydney in 2007. 